Copyright (C) 2020 University of Bucharest Printed in Romania. All rights reserved ISSN print: $1224-5984$

ISSN online: $2248-3942$
Rom Biotechnol Lett. 2020; 25(5): 2018-2025

doi: $10.25083 / \mathrm{rbl} / 25.5 / 2018.2025$

Received for publication, April, 16, 2018

Accepted, June, 15, 2018

Original paper

\title{
Prevalence and Genotypes of Shiga Toxin (Verotoxin) - Producing Escherichia coli in Romanian Food
}

\section{RODICA NICULINA TANASUICA ${ }^{1,2}$, FLORICA BARBUCEANU ${ }^{2}$, LAURENTIU- MIHAI CIUPESCU ${ }^{1 *}$, RODICA DUMITRACHE ${ }^{1}$, GABRIEL PREDOI ${ }^{2}$}

${ }^{1}$ Institute for Hygiene and Veterinary Public Health, Campul Mosilor 5, 021201, Bucharest, Romania

${ }^{2}$ University of Agronomic Sciences and Veterinary Medicine of Bucharest - Faculty of Veterinary Medicine, Splaiul Independentei 105, 050097, Bucharest, Romania

\begin{abstract}
In the background of the severe hemolytic-uremic syndrome outbreak occurred in Romania at the beginning of 2016, 1484 different milk and meat food units were investigated for Shiga-toxin producing Escherichia coli (STEC) contamination. Prevalence of the virulence genes was calculated and the isolated STEC strains were pheno-genotypic characterized by chromogenic media technique, PCR and DNA sequencing. Sixty-nine STEC isolates were recovered and, of the all food matrices, ovine carcass swabs were the most contaminated $(37 / 1484 ; 2.49 \%)$, followed by minced meat and meat $(22 / 1484 ; 1.48 \%)$ and milk products $(7 / 1484 ; 0.047 \%)$. Most prevalent Shiga-toxin encoding gene was stx2 (53/69; $76.81 \%)$, followed by stx1 $(44 / 69 ; 63.76 \%)$; the eae - intimin encoding gene represented $5.79 \%$ (4/69). Among these isolates, one O157 STEC and two non-O157 serotypes, O26 and O113 were identified. Sanger sequencing showed single nucleotide polymorphism for stx genes and more than $10 \%$ differences in nucleotide and amino acids structure were encountered on virulence genes and/or eae and serogroup-associated genes. Our findings underlines the importance of the pheno-genotyping characterization of STECs in food relating to public safety and the continuous surveillance for non-O157 STEC emerging serotypes that represents a real support for the surveillance of new STEC infections in humans.
\end{abstract}

Keywords Shiga-like toxin producing Escherichia coli (STEC)/Verotoxin producing Escherichia coli (VTEC); PCR, DNA sequencing.

To cite this article: TANASUICA RN, BARBUCEANU F, CIUPESCU LM, DUMITRACHE R, PREDOI G. Prevalence and Genotypes of Shiga Toxin (Verotoxin) Producing Escherichia coli in Romanian Food. Rom Biotechnol Lett. 2020; 25(5): 2018-2025. DOI: $10.25083 / \mathrm{rbl} / 25.5 / 2018.2025$

*Corresponding author: LAURENTIU MIHAI CIUPESCU, Institute for Hygiene and Veterinary Public Health, Campul Mosilor 5, 021201, Bucharest, Romania, Tel: +40770547274

E-mail: ciupescu_laurentiu@yahoo.com 


\section{Introduction}

Even though it is usually harmless and beneficial inhabitant of the intestinal tract, Escherichia coli (E. coli) is increasingly encountered as pathogenic with remarkable versatility in causing diseases in humans and animals. Pathogenic E. coli is becoming more incriminated in foodborne outbreaks and, among pathotypes, we can encounter Verocytotoxigenic E. coli (VTEC), Enterotoxigenic E. coli (ETEC), Enteroinvasive E. coli (EIEC), Enteropathogenic E. coli (EPEC), Enteroaggregative E. coli (EAggEC) and Diffusely adherent E. coli (DAEC) (J.P. NATARO \& al [1]). In the midst of these pathotypes, STEC is a major cause of gastroenteritis that may be complicated by hemorrhagic colitis or HUS (hemolyticuremic syndrome), which is the cause of fatal acute renal failure in small babies, because STEC produce toxins in the gastrointestinal lumens whereas the gut microflora is poorly developed (N.P. BANATVALA \& al [2], W.T.A. TODD \& al [3], S. RUBINO [4]).

Since its identification in 1982, STEC O157:H7 has been the cause of a series of outbreaks in Europe, Japan and North America (P.I. TARR \& al [5]). The natural principal reservoir implicated in most of the reported outbreaks were the domestic ruminants, especially cows, sheep and goats (C. GERMINARIO \& al [6], M. BLANCO \& al [7], M. BLANCO \& al [8], M.A. Karmali [9]). The outbreak vehicle can be represented by undercooked meat, unpasteurized dairy products, vegetables or water contaminated by the feces of animals and humans. Person-to-person transmission has been also documented (J.C. PATON \& al [10], CDC \& al [11], A.W. PATON \& al [12]).

STEC elaborates two phage-encoded cytotoxins Stx 1 and Stx2, encoded by two genes stx 1 and stx2. These toxins can be combined or not with another virulence factor called intimin, which is a protein encoded by the eae gene. The intimin is responsible for the intimate attachment of STEC to the intestinal epithelial cells causing attaching-andeffacing lesions in the intestinal mucosa (M. BLANCO \& al [8], M.A. KARMALI [9]). Sometimes, it has been demonstrated the loss and transfer of stx genes by pathogenic STEC during human infections due to stx carrying phage as mobile elements. This hypothetical loss of virulence genes should be always investigated, because this can lead to a false consideration of a safe food (A.W. PATON \& al [12]).

In 2016, 28 Member States reported 6378 human cases and 10 deaths, which represents an increase of $8.3 \%$ compared with 2015 (EFSA [13]). Instead of STEC O157, which was the most frequent serotype, for the first time, in 2016, the STEC O26 became the most reported one in HUS human cases in EU. In the USA, by comparison with EU, the $\mathrm{O} 157$ serotype is still persistent (K.G.J. POLLOCK \& al [14]). Regarding STEC prevalence in food in EU in 2016, the meat and meat products were the most contaminated matrices (9242), followed by milk and milk products (4119) and fruits/ vegetables (1543) (EFSA [13]). In the past, outbreaks caused by STEC O26 have been associated with unpasteurized milk and dairy products in Austria, Belgium and Italy (C. GERMINARIO \& al [6], K. DE SCHRIJVER \& al [15]). In addition, in Romania a large outbreak occurred in the early of 2016, extended rapidly to other European countries, which involved STEC O26 and other non-O157 STEC strains (EFSA [13], E. PERON \& al [16]).

Notwithstanding the EU Regulation No. 20173/2005, which states a STEC microbiological criteria only for sprouts seeds, this paper summarizes a monitoring STEC program in meat and milk products conducted in Romania in 2016 and the microbiological and molecular investigations on the STEC isolates occurred under this program. In the same time, this study asserts the importance of the STEC surveillance in foods in Romania for non- O157 STEC, which give real support to the surveillance of STEC diseases in humans.

\section{Materials and Methods}

\section{Samples}

Bacteriological and molecular investigations were performed in the Institute for Hygiene and Veterinary Public Health in the frame of a national monitoring program for STEC surveillance in 1484 meat and milk samples as Table 2.

\section{STEC detection and isolation}

Screening of virulence genes st 1 , st $x 2$, eae and serogroup- associated genes O157, O145, O111, O103, O26, O104 were done according ISO 13136:2012 [17] with minor modifications. The PCR screening step consisted in the detection of stx 1 and stx 2 genes from DNA extraction of a one $\mathrm{mL}$ enrichment broth, followed, in case of a stx positive result, by the eae and serogroup-associated genes identification from the same DNA extract. For stx positive samples, one loop of enrichment was dispersed on TBX agar (Oxoid, Basingstoke Hampshire, England) and fifty colonies were isolated. Pools of ten colonies were then tested for stx and eae by PCR. Finally, the intention was to isolate a single bacterial cell that contains stx and/or eae genes and/or the serogroup-associated genes. DNA was extracted with InstaGene Matrix ${ }^{\circledR}$ (Bio-Rad, Marnes la coquette, France) from $1 \mathrm{~mL}$ sample enrichment broth or from one $E$. coli colony according the manufacturer protocol for Gram-negative bacteria. Real-time PCR amplifications were performed on the Applied Biosystems 7900 HT Fast Real time PCR instrument (Applied Biosystems, Foster City, California 94404, USA) within a total reaction mixture of $20 \mu \mathrm{L}$ containing $2 \mu \mathrm{L}$ DNA, $0.5 \mu \mathrm{M}$ (each) primer, $0.2 \mu \mathrm{M}$ probe (Invitrogen, Carlsbad, USA), $10 \mu \mathrm{l}$ of GoTaq ${ }^{\circledR}$ qPCR Master Mix 2.0 (Promega Corporation, Madison, USA) and PCR grade water to final volume. The real-time PCR thermal conditions consisted in a first step of initial denaturation of DNA and Taq polimerase activation at $95^{\circ} \mathrm{C}$ for $10 \mathrm{~min}$, followed by 40 cycles of denaturation at $95^{\circ} \mathrm{C}$ for $15 \mathrm{sec}$, and annealing and extension at $60^{\circ} \mathrm{C}$ for one minute. Negative control (E. coli K12) and positive control strains of STEC received from the European Reference Laboratory for E. coli, Italy, were used.

All positive strains for one of the target virulent genes (stx and/or eae) were analyzed by phenotypic techniques. After overnight incubation at $37^{\circ} \mathrm{C}$, it was evaluated the ability to convert tryptophan into indole using tryptone broth (Oxoid) and Kovács reagent (Merck KGaA, Darmstadt, Germany), to ferment the sorbitol on CT-SMAC (Oxoid), 
the glucoronidase and galactosidase activity on chromID O157:H7 (bioMérieux, Marcy 1 'Etoile, France) and the hemolysin activity by culturing on $5 \%$ blood agar plates.

The isolated strains were preserved on Criobilles (bioMérieux) in a $-80^{\circ} \mathrm{C}$ freezer until sequencing.

\section{Nucleotide sequencing}

The stx 1 , st $x 2$, eae, wzxO157 and wzyO 113 genes were amplified in a Bio-Rad C1000 PCR instrument (Bio-Rad). PCR reaction consisted in a $25 \mu \mathrm{L}$ reaction mixture containing $2 \mu \mathrm{L}$ of 10 to $50 \mathrm{ng}$ extracted DNA with InstaGene Matrix (Bio-Rad), $0.5 \mu \mathrm{M}$ of each primer (Table 1), 1U Maxima Hot Start Taq DNA Polymerase (Thermo Fisher Scientific, Waltham, USA), 1x buffer, $2.5 \mathrm{mM} \mathrm{MgCl}_{2}$, and $0.5 \mu \mathrm{M}$ of each deoxynucleoside triphosphate (dNTP). PCR was performed with initial denaturation at $95^{\circ} \mathrm{C}$ for $5 \mathrm{~min}$, followed by 35 cycles of $95^{\circ} \mathrm{C}$ for $30 \mathrm{sec}, 52^{\circ} \mathrm{C}$ for $50 \mathrm{~s}$ and $72^{\circ} \mathrm{C}$ for $30 \mathrm{sec}($ st $x 1) /$ $58^{\circ} \mathrm{C}$ for $50 \mathrm{~s}$ and $72^{\circ} \mathrm{C}$ for $30 \mathrm{sec}($ stx 2$) / 62.5^{\circ} \mathrm{C}$ for $30 \mathrm{~s}$ and $72^{\circ} \mathrm{C}$ for $30 \mathrm{sec}(e a e) / 58^{\circ} \mathrm{C}$ for $30 \mathrm{~s}$ and $72^{\circ} \mathrm{C}$ for $30 \mathrm{sec}(w z x \mathrm{O} 157) / 60^{\circ} \mathrm{C}$ for $30 \mathrm{~s}$ and $72^{\circ} \mathrm{C}$ for $1 \mathrm{~min}$ $(w z y \mathrm{O} 113)$, and a final extension at $72^{\circ} \mathrm{C}$ for $7 \mathrm{~min}$.
The amplicons were directly sequenced by reverse and forward primer previously used (Table 1) in each direction using an ABI BigDye Terminator 3.1 cycle sequencing kit (Life Technologies Corporation, Carlsbad, USA) according the manufacturer protocol.

\section{Phylogenetic analysis}

Homology searches for stx, eae, wyxO157 and wyzO113 partial sequences were performed using BLAST through the National Center for Biotechnology Information (NCBI; http://www.ncbi.nlm.nih.gov/). The nucleotide sequences obtained were aligned using of ClustalW from MEGA7: Molecular Evolutionary Genetics Analysis version 7.0 for bigger datasets (S. KUMAR \& al [21]). A phylogenetic tree was constructed by the neighborjoining method, and genetic distances were calculated by the Kimura two-parameter method (B. EFRON \& al [22]). The resulting tree was drawn with the same MEGA7 software. The Gen Bank strains used for comparison of the isolated STEC strains in this study were KM596779, DQ452096, KU158845, LC151942, KY466168, FR875155, AJ579368, AJ879906, AJ57930 and EU499352.

Table 1. Primers used for DNA sequencing

\begin{tabular}{|c|c|c|c|c|}
\hline Primer & Direction & Primer sequence (5'-3') & $\begin{array}{l}\text { Fragment } \\
\text { size (bp) }\end{array}$ & Reference \\
\hline \multirow{2}{*}{ stx 1} & Forward & ACACTGGATGATCTCAGTGG & \multirow{2}{*}{614} & \multirow{4}{*}{$\begin{array}{l}\text { (P. K. FAGAN \& } \\
\text { al }[18])\end{array}$} \\
\hline & Reverse & CTGAATCCCCCTCCATTATG & & \\
\hline \multirow{2}{*}{ stx 2} & Forward & CCATGACAACGGACAGCAGTT & \multirow{2}{*}{779} & \\
\hline & Reverse & CCTGTCAACTGAGCAGCACTTTG & & \\
\hline \multirow{2}{*}{$w z x \mathrm{O} 157$} & Forward & GCTGCTTATGCAGATGCTC & \multirow{2}{*}{133} & (S.R. MONDAY \\
\hline & Reverse & CGACTTCACTACCGAACACTA & & $\&$ al $[19])$ \\
\hline \multirow{2}{*}{$w z y \mathrm{O} 113$} & Forward & AGCGTTTCTGACATATGGAGTG & \multirow{2}{*}{593} & (A.W. PATON \& \\
\hline & Reverse & GTGTTAGTATCAAAAGAGGCTCC & & al [20]) \\
\hline \multirow{2}{*}{ eae } & Forward & GACCCGGCACAAGCATAAGC & \multirow{2}{*}{384} & (A.W. PATON \& \\
\hline & Reverse & CCACCTGCAGCAACAAGAGG & & al [12]) \\
\hline
\end{tabular}

\section{Results and Discussion}

Of 1484 samples of milk and meat with bovine and ovine origin, 330 samples were detected as positive by screening real-time PCR for one or both verocytotoxin genes and/or eae and serogroup- associated genes (samples named as presumptive), out of which STEC was isolated from 69 samples (Table 2). Five STEC's were found in milk and milk products, 16 in meat and meat products and 32 in swab carcass, all of them containing only the stx 2 gene. st 1 gene was found in the strains isolated from three milk products, nine meat and meat products and 32 swabs. Twenty-eight stx $1 /$ st $x 2$ mixed genotype strains were found in one milk product, three meat products (one bovine minced meat and two mixed bovine/ovine minced meat) and 24 swabs (two from bovine and 22 from ovine). One stx2/eae 0157 STEC genotype was isolated from a bovine meat and a minced bovine meat contained a stx1/eae O26 STEC strain. A stxl O113 STEC genotype was found in a minced mixed meat of bovine/ovine origin.

Table 2. STEC detection results - The origin and matrix involved

\begin{tabular}{|c|c|c|c|c|c|}
\hline Origin & Matrix & Negative & Positive & Presumptive & Total \\
\hline Slaughterhouse & Swab carcass bovine & 271 & 3 & 32 & 306 \\
\hline Slaughterhouse & Swab carcass ovine & 139 & 37 & 19 & 195 \\
\hline Farm & Milk & 51 & 3 & 11 & 65 \\
\hline Row milk dispenser & Milk & 93 & 0 & 17 & 110 \\
\hline Milk processing plant & Milk products & 16 & 2 & 5 & 23 \\
\hline Markets and fairs & Milk and milk products & 29 & 0 & 21 & 50 \\
\hline Market, supermarket, hypermarket & Milk and milk products & 214 & 2 & 26 & 242 \\
\hline Market, supermarket, hypermarket & Meat, minced meat, meat product & 147 & 15 & 70 & 232 \\
\hline Steakhouse & Meat, minced meat, meat product & 99 & 4 & 38 & 141 \\
\hline Butcher shops & Meat, minced meat, meat product & 76 & 2 & 16 & 94 \\
\hline Restaurant & Meat, minced meat, meat product & 19 & 1 & 6 & 26 \\
\hline Total & & 1154 & 69 & 261 & 1484 \\
\hline
\end{tabular}


Regarding phenotypic characterization, all isolated STEC strains (less strain STEC O157) disclosed fermentation of sorbitol and glucoronidase and galactosidase activity. Only five strains, including STEC O157 and O113, displayed hemolysin activity.

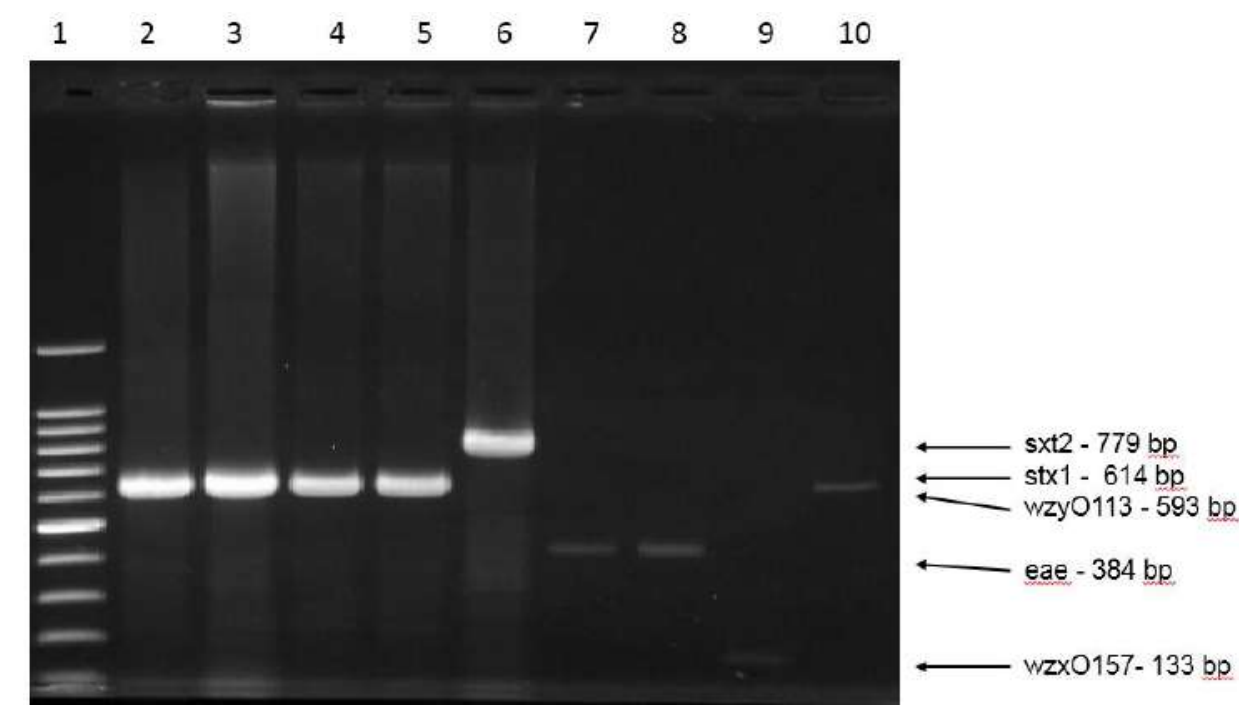

Figure 1. Conventional PCR. Lane 1- 100 bp DNA Ladder; lane 2- strain 215 (genotype stx1/O113 positive); lane 3- strain 315 (genotype stx1/eae positive); lane 4- strain 415 (genotype stx 1 positive); lane 5- strain 515 (genotype stx 1 positive); lane 6- strain 725 (genotype stx2/eae/O157 positive); lane 7- strain 315 (eae positive); lane 8- strain 725 (eae positive); lane 9- strain 725 (wzxO157 positive); lane 10- strain 215 (wzyO113 positive).

Based on the similarity of genes between the isolates and the hemolysin activity, only five strains were chosen and directed to DNA sequencing, strain 215 (genotype st $1 / 0113$ positive), strain 315 (genotype stx1/eae positive), strain 415 (genotype st $x 1$ positive), strain 515 (genotype st 1 positive) and strain 725 (genotype stx2/eae/O157 positive). The sequences were blasted and compared with other STEC strains at nucleotides level, obtaining a phylogenetic tree as Figure 2.

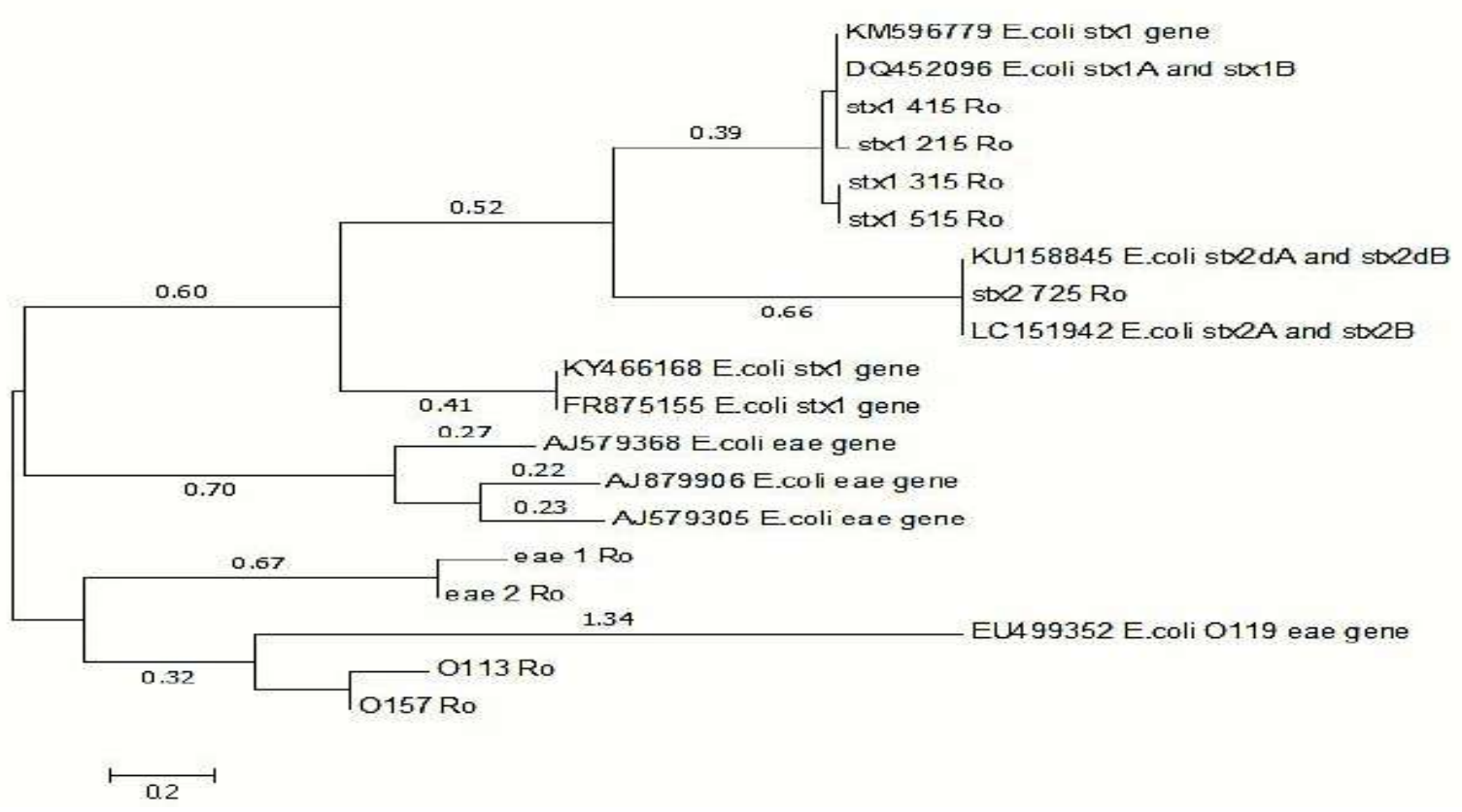

Figure 2. Phylogenetic tree for five Romanian STEC isolates (Ro) based on the neighbor-joining method (M. KIMURA [23], S.F. ALTSCHUL \& al [24]). The branch lengths were indicated by the scale of 0.2 , expressed in number of changes in SNPs (single-nucleotide polymorphisms) per strains. 
Protein conformation of the translated partial sequence genes was compared to other Gen Bank strains, resulting some differences as Figures 3-6.

Alignment of the stx 1 and stx 2 discussed sequence genes with other Gen Bank strains, revealed 2 to 25 SNPs differences according Figure 2 (215 and 415 strains have only 5 and 2 base pairs differences, respectively; strains 315 and 515 encountered 21 nucleotide differences comparing to the Blast sequences KY884002 and GQ429155). The predicted amino acid configuration after translation was identical between strains 315 and 515, but differed from the others by leucine, valine, tyrosine, alanine, cysteine, threonine, glycine and isoleucine. The 215 strain is different from all the other strains by methionine, glutamate and isoleucine. The 415 strain is different from others only by serine, but contain in the same time an amino acid with an unknown termination $(\mathrm{X})$.

Regarding the alignment of the eae gene (Fig. 5), the results indicated 39 nucleotide differences between the two Romanian strains and only four differences with the foreign genes. According figure 6 there are significant amino acid differences between the eae Romanian strains (tyrosine, glutamine, serine, asparagine, alanine, aspartate, isoleucine, valine, glycine and proline) and only few differences between the strain 725 Ro eae gene and the Gen Bank genes (tyrosine, glutamine, serine, proline).

The obtained partial sequence genes of the STEC strains stx 1215 Ro, stx 1315 Ro, stx 1415 Ro, st $x 1515$ Ro and stx 2725 Ro were loaded in Gen Bank as Romanian stx sequences.

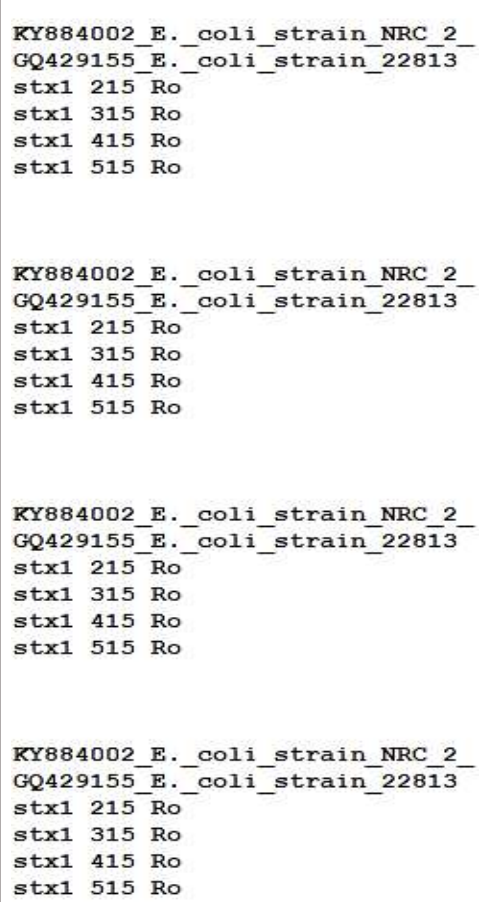

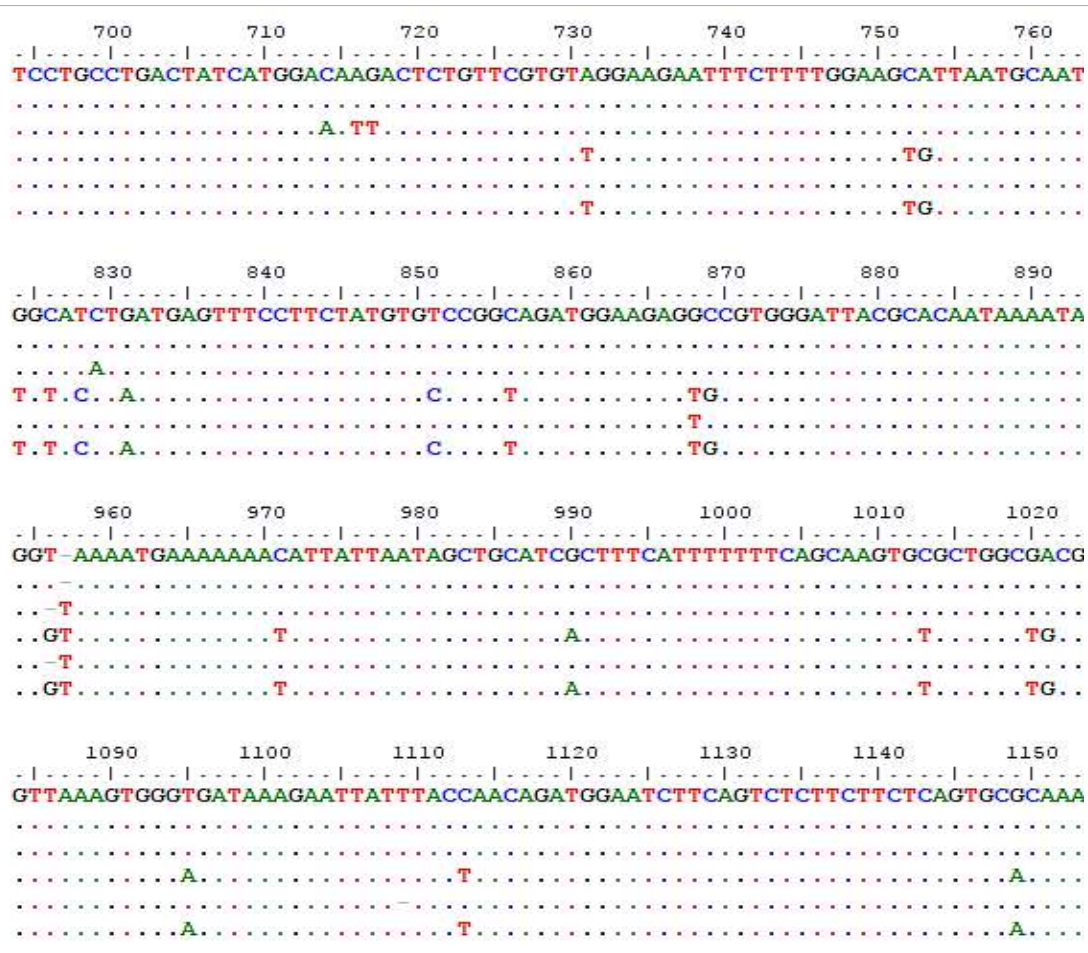

Figure 3. Graphical representation of stx nucleotides differences.

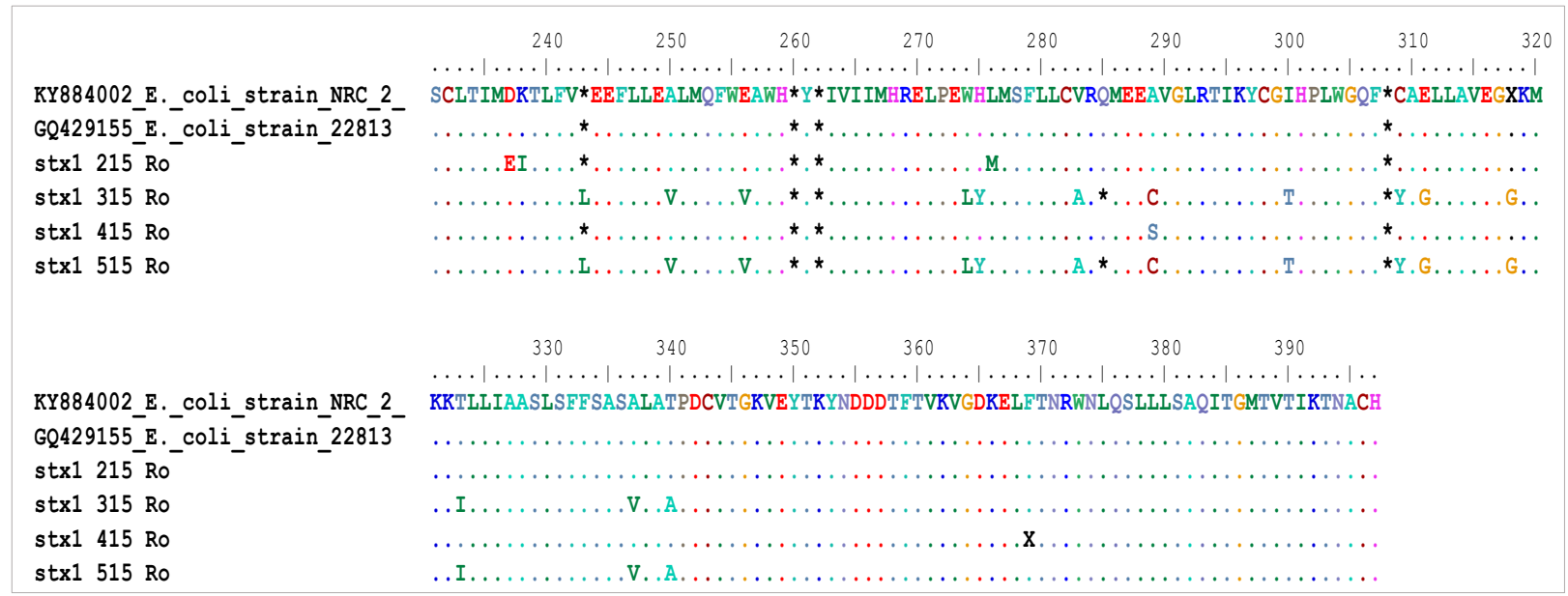

Figure 4. Graphical representation of Stx amino acids differences. 


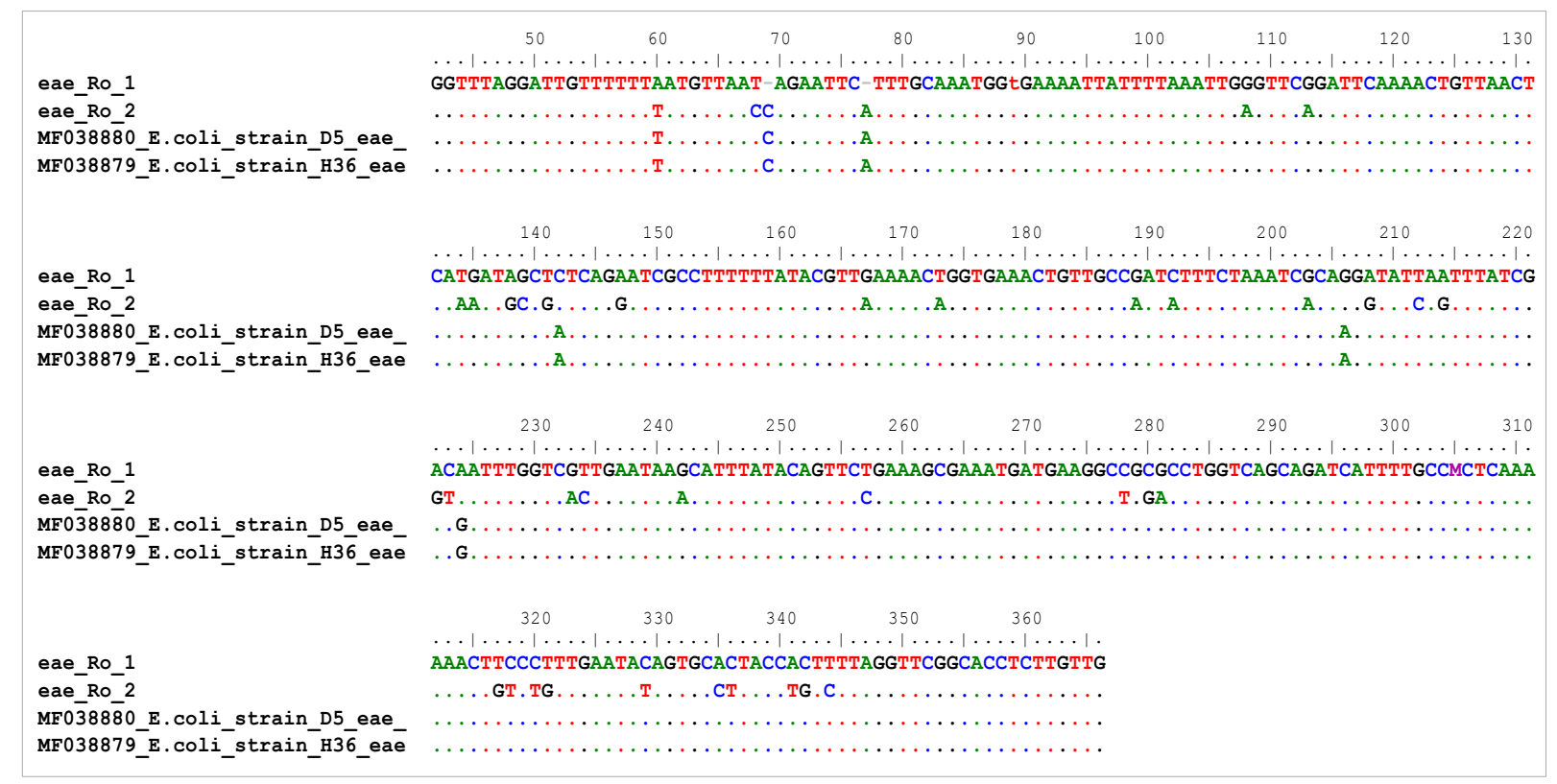

Figure 5. Graphical representation of eae nucleotides differences.

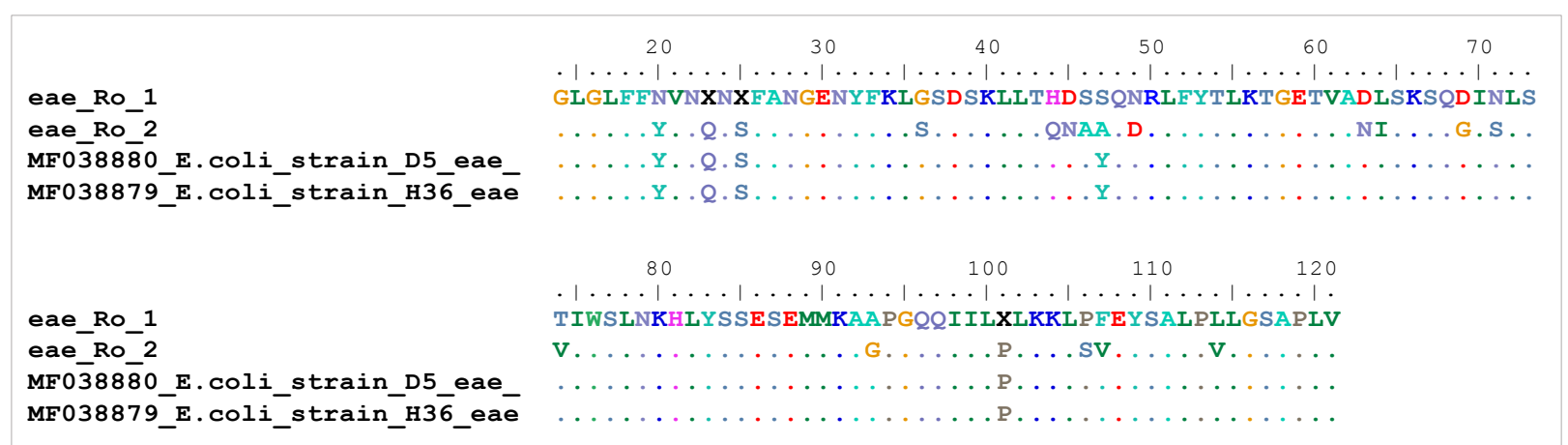

Figure 6. Graphical representation of intimin amino acids differences.

According ISO/TS 13136:2012 [17], a sample is positive when the isolation of the STEC is achieved. In the same time, the same method uses the syntagm "presumptive presence of STEC", meaning that the PCR is positive from the sample enrichment, but the isolation step is not achieved (maybe the STEC previously detected by PCR cannot be isolated because it is present in sample in such small amount that does not allow the isolation). For PCR the limit of detection is about two to ten genome copies/1 $\mathrm{ml}$ of enrichment broth, but for STEC isolation the limit of detection is more than $100 \mathrm{CFU} / 25 \mathrm{~g}$ of sample depending on the existent background flora in the sample (ISO/TS 13136:2012 [25]). Because stx genes can be present in nonpathogenic organism like phages, the screening PCR step may have an inaccurate estimation of food safety risk unless a viable strain has been isolated (EFSA [26]). In this study, STEC strains were isolated from $4.65 \%$ of food samples, a small percent comparing to other diseases or other countries (K.G.J. POLLOCK \& al [14], K. DE SCHRIJVER \& al [15]). A bigger percent, $17.58 \%$ of tested samples were included in the category of STEC presumptions, an older study yielding only such results (L.M. CIUPESCU \& al [27]).
Most contaminated matrix analyzed in our study was the carcass swab $(40 / 69 ; 57.97 \%)$, followed by meat $(22 / 60 ; 31.88 \%)$ and milk $(7 / 69 ; 10.14 \%)$. The positive milk and milk products mostly originated in bovines $(6 / 7$; $85.71 \%)$ as well as the meat and meat products $(14 / 22$; $63.63 \%)$. The ovine swabs were the most contaminated samples $(37 / 40 ; 92.5 \%)$, being in the same trend as other European countries, where a higher percent of STEC isolates was detected in 2016 in sheep and goats $(18,5 \%)$ than cows (EFSA [13]).

Worldwide, meat and milk products may have $10 \%$ to $30 \%$ STEC (V.M. BOHAYCHUK \& al [28], J. BLANCO \& al [29], C.R. USEIN \& al [30]). It is highly recommended to use very sharp HACCP procedures at slaughterhouse level to prevent contamination during evisceration and skinning of ruminants. In addition, the hygiene of food preparation meat in the kitchen should be very rigorous. If we are dealing with food that will be consumed in a raw state, then testing them for STEC should be compulsory because it is not enough to go only for assessing the hygiene microbiological criteria (tests that detects the $E$. coli glucuronidase positive or counts $E$. coli by the presumptive test). Even if the carcass swabs and meat were the most contaminated matrices, meat is consumed 
only after thermal treatment. Regarding milk and milk products, there are some cheese items that are mostly eaten in row state (only fermentation), giving the possibility to produce STEC disease to consumers [K. DE SCHRIJVER \& al [15], C. R. USEIN \& al [30], ECDC [31].

Other authors found st 2 /eae STEC genotype strains (altogether with or without stx 1 ) in human cases and food. These strains may lead to HUS (stx2/eae mainly) or diarrhea diseases (stx1/eae) (C. R. USEIN \& al [30]). The same authors claimed that STEC O26 was involved in the 2016 outbreak when milk products were incriminated mostly. In-depth investigations on seeking links between food and human strains should further be conducted, because, in this study, in food were discovered 53 strains carrying st $x 2$ gene and 44 strains carrying st $x 1$ gene (of these, 28 were mixed st $x 1 /$ st $x 2$ genotype strains) and only one O26 STEC strain harboring stx1 and eae genes, which was actually isolated in meat. No STEC O26 strain was isolated in milk and milk products in this study.

Regarding phenotypic characteristics, the results showed that STEC strains isolated in this study do not have significant differences than other reported STECs (all the E. coli, less serogroup O157, ferments sorbitol and have glucuronidase and galactosidase activity). Only five strains exhibited the property to excrete hemolysin, a feature that can determine the HUS syndrome in children (P.K. FAGAN \& al [18]).

By Sanger DNA sequencing, we analyzed, five STECs isolated from food. The obtained st $x$ and eae partial sequence genes were confirmed to be variants of related Gen Bank genes because their sequences differed less than $10 \%$ from the previously reported variants. Less variability was encountered in case of stx genes, even though the origin of this gene is in lambda phages, entities that can determine more genetic variabilities than other mobile elements (S.A. MAURO \& al [32]). Greater variability was observed in the case of eae genes but this is not something out of the ordinary because other authors have come to the same conclusions (E.A. MCGRAW \& al [33], W.L. ZHANG \& al [34]). Overall, these results indicate common origin of Romanian isolates comparing to homologous Gen Bank isolates related to stx and eae genes sequences. The newly stx sequences assigned in Gen Bank can contribute to earlier investigations in case of identifying slaughtering ruminant and milk processing plants as a source of STEC O157 and non- O157.

\section{Conclusion}

In this study, stx2 STEC genotypes were the most frequently in the monitored food and the non-O157 genotypes found here could be involved in the future in new emerging outbreaks in Romania as O26 in 2016. Bovine meat and meat products were the most contminated matrices - this is similar to other Europe regions. In Romania, other STEC sources should be investigated in the future, like ruminant farms in other EU countries. Based on the pheno-genotypic profiles, the isolated STEC strains in this study are commonly found worldwide and continuous monitoring programs should be conducted in the future for earlier identifying the sources of STEC infections in humans.

\section{Acknowledgements}

This work was supported by funds from the National Sanitary Veterinary and Food Safety Agency in the frame of the 2016 national STEC monitoring program. R.N.T. is the recipient of a doctoral fellowship (No. 241/2016) financed by the University of Agronomic Sciences and Veterinary Medicine of Bucharest.

\section{References}

1. J.P. NATARO, J.B. KAPER. Diarrheagenic Escherichia coli. Clinical Microbiology Reviews, 11(1), 142-201 (1998).

2. N.P. BANATVALA, M. GRIFFIN, K.D. GREENE, T.J. BARRETT, W.F. BIBB, J.H. GREEN, J.G. WELLS and the Hemolytic Uremic Syndrome Study Collaborators. The United States National Prospective Hemolytic Uremic Syndrome Study: microbiologic, serologic, clinical, and epidemiologic findings. J. Infect. Dis. 183:1063-1070 (2001).

3. W.T.A. TODD, S. DUNDAS. The management of VTEC O157 infection. Int. J. Food Microbiol, 66:103-110 (2001).

4. S. RUBINO, P. CAPPUCCINELLI, D.J. KELVIN. Escherichia coli (STEC) serotype O104 outbreak causing haemolytic syndrome (HUS) in Germany and France. J Infect Dev Ctries, (6):437-40. DOI: 10.3855/jidc.2172 PMID: 21727641 (2011)

5. P.I. TARR, T.E. BESSER, D.D. HANCOCK, W.E. KEENE and M. GOLDOFT. Verotoxigenic Escherichia coli infection: U.S. overview. J. Food Prot. 60:1466-1471 (1997).

6. C. GERMINARIO, A. CAPRIOLI, M. GIORDANO, M. CHIRONNA, M. S. GALLONE, S. TAFURI, F. MINELLI, A. MAUGLIANI, V. MICHELACCI, L. SANTANGELO, O. MONGELLI, C. MONTAGNA, G. SCAVIA, on behalf of all participants of the Outbreak investigation team. Community-wide outbreak of haemolytic uraemic syndrome associated with Shiga toxin 2-producing Escherichia coli O26:H11 in southern Italy, summer 2013. Euro Surveill. 21(38):pii=30343. https://doi. org/10.2807/1560-7917.ES.2016.21.38.30343 (2016).

7. M. BLANCO, J.E. BLANCO, J. BLANCO, E.A. GONZÁLEZ, A. MORA, C. PRADO, L. FERNÁNDEZ, M. RIO, J. RAMOS and M.P. ALONSO. Prevalence and characteristics of Escherichia coli serotype O157:H7 and other verotoxin-producing $E$. coli in healthy cattle. Epidemiol. Infect. 117:251-257 (1996).

8. M. BLANCO, J.E. BLANCO, A. MORA, J. REY, J.M. ALONSO, M. HERMOSO, J. HERMOSO, M.P. ALONSO, G. DHABI, E.A. GONZÁLEZ, M.I. BERNÁRDEZ and J. BLANCO. Serotypes, virulence genes, and intimin types of Shiga toxin (verotoxin)producing Escherichia coli isolates from healthy sheep in Spain. J. Clin. Microbiol. 41:1351-1365 (2003).

9. M.A. KARMALI. Infection by verocytotoxin-producing Escherichia coli. Clin. Microbiol. Rev. 2:5-38 (1989).

10. J.C. PATON and A.W. PATON. Pathogenesis and diagnosis of Shiga toxin-producing Escherichia coli infections. Clin. Microbiol. Rev. 11:450-479 (1998).

11. Centers for Disease Control and Prevention (CDC). Outbreak of Escherichia coli O104:H4 infections associated with sprout consumption - Europe and North America, May-July 2011. MMWR Morb Mortal Wkly Rep. 62(50):1029-31.PMID: 24352067 (2013). 
12. A.W. PATON \& J.C. PATON. Detection and characterization of Shiga toxigenic Escherichia coli by using multiplex PCR assays for stx 1 , st 2 , eaeA, enterohemorrhagic E. coli hlyA, rfbO111, and rfbO157. J Clin Microbiol. 36:598-602 (1998).

13. EFSA (European Food Safety Authority) and ECDC (European Centre for Disease Prevention and Control), The European Union summary report on trends and sources of zoonoses, zoonotic agents and food-borne outbreaks in 2016. EFSA Journal 2017; 15(12):5077, 228 pp. https://doi.org/10.2903/j.efsa.2017.5077 (2017).

14. K.G.J. POLLOCK, S. BHOJANI, T.J. BEATTIE, L. ALLISON, M. HANSON, M.E. LOCKING \& J.M. COWDEN. Highly Virulent Escherichia coli O26, Scotland. Emerging Infectious Diseases, 17(9), 17771779. http://doi.org/10.3201/eid1709.110199 (2011).

15. K. DE SCHRIJVER, G. BUVENS, B. POSSÉ, D. VAN DEN BRANDEN, O. OOSTERLYNCK, L. DE ZUTTER, K. EILERS, D. PIÉRARD, K. DIERICK, R. VAN DAMME-LOMBAERTS, C. LAUWERS, R. JACOBS. Outbreak of verocytotoxin-producing E. coli $\mathrm{O} 145$ and O26 infections associated with the consumption of ice cream produced at a farm, Belgium, 2007. Euro Surveill. 13(7):8041.PMID: 18445416 (2008).

16. E. PERON, A. ZAHARIA, L.C. ZOTA, E. SEVERI, O. MÅRDH, C. USEIN, M. BĂLGRĂDEAN, L. ESPINOSA, J. JANSA, G. SCAVIA, A. RAFILA, A. SERBAN, A. PISTOL. Early findings in outbreak of haemolytic uraemic syndrome among young children caused by Shiga toxin-producing Escherichia coli, Romania, January to February 2016. Euro Surveill. 21(11):pii=30170. DOI: http://dx.doi.org/10.2807/15607917.ES.2016.21.11.30170 (2016)

17. International Organization for Standardization. ISO/TS 13136:2012 Microbiology of food and animal feed - Realtime polymerase chain reaction (PCR)-based method for the detection of food-borne pathogens - Horizontal method for the detection of Shiga toxin-producing Escherichia coli (STEC) and the determination of O157, O111, O26, O103 and O145 serogroups. Technical Specifications: ISO; 2012.

18. P.K. FAGAN, M.A. HORNITZKY, K.A. BETTELHEIM, S.P. DJORDJEVIC. Detection of Shiga-Like Toxin (stx1 and stx2), Intimin (eaeA), and Enterohemorrhagic Escherichia coli (EHEC) Hemolysin (EHEC hlyA) Genes in Animal Feces by Multiplex PCR. Applied and Environmental Microbiology, 65(2), 868-872 (1999).

19. S.R. MONDAY, A. BEISAW, P.C. FENG. Identification of Shiga toxigenic Escherichia coli seropathotypes A and B by multiplex PCR. Mol Cell Probes; 21: 308-11 (2007).

20. A.W. PATON \& J.C. PATON. Direct detection of Shiga toxigenic Escherichia coli strains belonging to serogroups O111, O157, and O113 by multiplex PCR. J Clin Microbiol. 37: 3362-5 (1999).

21. S. KUMAR, G. STECHER \& K. TAMURA. MEGA7: Molecular Evolutionary Genetics Analysis version 7.0. Molecular Biology and Evolution (2015)

22. B. EFRON, E. HALLORAN \& S. HOLMES. Bootstrap confidence levels for phylogenetic trees. Proc. Natl. Acad. Sci. USA 9313429-13434 (1996).

23. M. KIMURA. A simple method for estimating evolutionary rate of base substitutions through comparative studies of nucleotide sequences. Journal of Molecular Evolution 16:111-120 (1980).

24. S.F. ALTSCHUL, T.L. MADDEN, A.A. SCHAFFER, J. ZHANG, Z. ZHANG, W. MILLER \& D.J. LIPMAN.
Gapped BLAST and PSI-BLAST: a new generation of protein database search programs, Nucleic Acids Res. 25:3389-3402 (1997).

25. ISO/TS 13136:2012 Report on the primary validation of the PCR screening reactions and the determination of the performance parameters, based on the results of the analytical tests carried out within the EU-RL VTEC proficiency testing program (2009-2015) (http://www.iss.it/ binary/vtec/cont/EU_RL_VTEC_Method_performance CEN_ISO_TS_13136_2012_Rev1.pdf)

26. EFSA. Technical specifications for the monitoring and reporting of verotoxigenic Escherichia coli (VTEC) on animals and food (VTEC surveys on animals and food) on request of EFSA, The EFSA Journal 7, 1366 (2009).

27. L. M. CIUPESCU, I. M. NICORESCU, I. MIHAI, R. DUMITRACHE, R. TANASUICA. One-year follow up study for the detection of STEC in food of animal origin the presence of the main virulence genes, present and future potential risk for consumers. Scientific Works. Series C. Veterinary Medicine, vol. LXI, ISSN 20651295, 220-225 (2015).

28. V.M. BOHAYCHUK, G.E. GENSLER, R.K. KING, K.I. MANNINEN, O. SORENSEN, J.T. WU, M.E. STILES \& L.M. MCMULLEN. Occurrence of Pathogens in Raw and Ready-to-Eat Meat and Poultry Products Collected from the Retail Marketplace in Edmonton, Alberta, Canada. Journal of Food Protection, vol. 69, no. 9, pages 21762182 (2006).

29. J. BLANCO, M. BLANCO, J.E. BLANCO, A. MORA, E.A. GONZÁLEZ, M.I. BERNÁRDEZ, M.P. ALONSO, A. COIRA, A. RODRIGUEZ, J. REY, J.M. ALONSO, M.A. USERA. Verotoxin-Producing Escherichia coli in Spain: Prevalence, Serotypes, and Virulence Genes of O157:H7 and Non-O157 VTEC in Ruminants, Raw Beef Products, and Humans Exp Biol Med (Maywood), 228: 345-351 (2003).

30. C.R. USEIN, A.D. CIONTEA, C.M. MILITARU, M. CONDEI, S. DINU, M. OPREA, D. CRISTEA, V. MICHELACCI, G. SCAVIA, L.C. ZOTA, A. ZAHARIA, S. MORABITO. Molecular characterization of human Shiga toxin-producing Escherichia coli O26 strains: results of an outbreak investigation, Romania, February to August 2016. Euro Surveill., 22(47):pii=17-00148. https://doi.org/ 10.2807/1560-7917.ES.2017.22.47.17-00148 (2017).

31. European Centre for Disease Prevention and Control (ECDC) and European Food Safety Authority. (EFSA). Multi-country outbreak of Shiga toxin-producing Escherichia coli infection associated with haemolytic uraemic syndrome. Stockholm: ECDC; 5 Apr 2016. Available from: http://ecdc.europa.eu/en/publications/Publications/RRAEscherichia-coli-O26-Romania-Italy-April2016.pdf

32. S.A. MAURO \& G.B. KOUDELKA. Shiga Toxin: Expression, Distribution, and Its Role in the Environment. Toxins, 3(6), 608-625. http://doi.org/10.3390/toxins3060608 (2011).

33. E.A. MCGRAW, J. LI, R.K. SELANDER, T.S. WHITTAM. Molecular evolution and mosaic structure of alpha, beta, and gamma intimins of pathogenic Escherichia coli., Molecular Biology and Evolution, 1999, volume 16, Issue 1, pp. 12-22, https://doi.org/10.1093/oxfordjournals. molbev.a026032

34. W. L. ZHANG, B. KÖHLER, E. OSWALD, L. BEUTIN, H. KARCH, S. MORABITO, H. SCHMIDT. Genetic Diversity of Intimin Genes of Attaching and Effacing Escherichia coli Strains. Journal of Clinical Microbiology, 40(12), 4486-4492. http://doi.org/10.1128/ JCM.40.12. 4486-4492.2002 (2002). 